\title{
Comparison of Several Turning Frequencies During the Storage Period of Red-Legged Partridge (Alectoris rufa) Hatching Eggs
}

Original Article

Euthor(s)

González-Redondo P

(iD) https://orcid.org/0000-0002-3324-2861 Martínez-Domínguez AR'

(iD) https://orcid.org/0000-0003-3155-2812

Departamento de Ciencias Agroforestales, Escuela Técnica Superior de Ingeniería Agronómica, Universidad de Sevilla, 41013 Sevilla, Spain.

\section{-Mail Address}

Corresponding author e-mail address Pedro González-Redondo

Departamento de Ciencias Agroforestales, Escuela Técnica Superior de Ingeniería Agronómica, Universidad de Sevilla, 41013 Sevilla, Spain.

Phone: +34 954486454

Email: pedro@us.es

\section{- Keywords}

Egg turning, game farming, hatchability, redlegged partridge, egg storage.

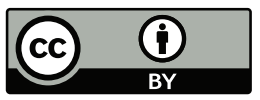

Submitted: 06/September/2018 Approved: 02/May/2019

\section{ABSTRACT}

The effects of three egg-turning regimes during the pre-incubation storage period on egg weight loss, hatchability, embryonic mortality, chick weight at hatching and incubation length of red-legged partridge (Alectoris rufa) compared with unturned eggs were investigated. Two hundred eggs were allocated to four 50-egg batches stored at $15^{\circ} \mathrm{C}$ and $80 \% \mathrm{RH}$ that being turned one, four and 24 times a day or remaining unturned, respectively. Eggs were incubated at $37.8^{\circ} \mathrm{C}$ and $55 \% \mathrm{RH}$ during the first 21 days and at $37.5^{\circ} \mathrm{C}$ and $75 \% \mathrm{RH}$ until hatching. Fertility was $70.5 \%$ and a good hatchability performance was obtained, characterised by $81.6 \%$ hatchability of fertile eggs, and weight losses of $0.78 \%$ during storage and of $10.04 \%$ during the first 21 days of incubation, $13.6 \pm 0.1 \mathrm{~g}$ hatchling weight, and incubation length of $23.45 \pm 0.07$ days (mean \pm SEM). Hatchability, embryonic mortality developmental stage, egg weight loss during storage and incubation, hatchling weight and length of the incubation period were not affected by the turning frequency or the absence of turning during storage. Higher hatching synchrony was observed for eggs turned four times a day compared with unturned eggs and eggs turned once a day. In conclusion, turning red-legged partridge eggs during mediumterm storage periods does not improve egg viability compared with unturned eggs.

\section{INTRODUCTION}

Red-legged partridges (Alectoris rufa) are raised in Mediterranean European countries (Portugal, Spain, Italy, and France) to provide birds in order both to ensure hunting stocks and to restock game reserve. This has given rise to a well-developed subsector of game farms (GonzálezRedondo et al., 2010). There are two keys to enhance $A$. rufa game farming productivity: egg handling before incubation and their artificial incubation. These aspects have been recently researched in order to review, assess, and improve the farmers' empirical know-how (e.g., González-Redondo \& De la Rosa Sánchez, 2009; González-Redondo, 2010; Gómez-de-Travecedo et al., 2014a, 2014b, 2014c; GonzálezRedondo \& Díaz-Merino, 2016). However, scientific assessment of several aspects of red-legged partridge egg handling during storage before incubation is still lacking. One of these aspects is egg turning during storage before incubation, which is a management practice applied in other poultry species to promote embryonic development and performance during subsequent incubation. Egg turning improves the interaction of the chorioallantoic membrane with the inner shell membrane, allowing adequate chorioallantoic membrane development when the typical incubation temperature is reached (Elibol et al., 2002; Damaziak et al., 2018). However, there is no consensus in the poultry literature regarding the mechanisms involved in the effects of egg 
turning during storage, nor on the optimal turning regime (Elibol et al., 2002; Damaziak et al., 2018). The most positive effects of egg turning during storage have been reported in eggs from older hens (Damaziak et al., 2018), or in low-quality eggs (Elibol et al., 2002). In general terms, more egg turning benefits are observed when eggs are stored for longer (over $14 \mathrm{~d}$ ) than shorter periods (reviewed by Elibol et al., 2002).

In this regard, literature recommendations for egg turning during storage in red-legged partridges are controversial. Alectoris rufa eggs are usually stored pointed-end down, and Setién (1991) recommends turning them every 30-60 min, Llauradó (1987) and Peña \& Caballero (1997) state turning twice a day suffices, while Cancho (1991) considers turning the eggs before incubation unnecessary. However, none of these authors base their recommendations on experimental data. In this context, scientific research has not yet elucidated the need for turning $A$. rufa eggs and, if turning were indeed necessary, the optimal turning frequency during the storage period. Moreover, red-legged partridge eggs store well for long periods (González-Redondo, 2010; Gómez-deTravecedo et al., 2014a) and it is possible that the potential effects of egg turning would be more clearly manifested if the eggs are stored for periods longer than 7-10 $\mathrm{d}$ recommended in the farming practices of this species (Cancho, 1991). Therefore, this research was conducted to evaluate the effects of several eggturning frequencies during a 15-day pre-incubation storage period on hatchability, embryonic mortality, egg weight loss, hatchling weight, and incubation length of artificially incubated red-legged partridge ( $A$. rufa) eggs.

\section{MATERIAL AND METHODS}

\section{Breeder flock and husbandry}

The hatching eggs used in this study were collected on a red-legged partridge game farm in El Ronquillo (province of Seville, southern Spain). Breeders were 2 and 3 yrs old, kept in pairs ( 1 male and 1 female) in outdoor cages $(50 \times 65 \mathrm{~cm})$, and fed a commercial feed containing $20 \%$ crude protein, $3.3 \%$ calcium, and 11.7 MJ metabolizable energy/kg (Avipacsa A-78 ${ }^{\circledR}$, Sanders, Dos Hermanas, Spain) ad libitum. Water was supplied ad libitum. During the reproductive resting period, the breeding flock was maintained under natural photoperiod. From December, birds were supplemented with artificial light, which was increased by $15 \mathrm{~min} / \mathrm{d}$ until a total 16 -h photoperiod (natural+artificial light) was achieved by January.

\section{Experimental procedure}

On March $5^{\text {th }}, 200$ recently-laid hatching eggs were divided into four treatments, consisting of 50 randomlyselected eggs weighing $19.64 \pm 0.10 \mathrm{~g}$ (mean \pm SEM). After disinfection for 10 min in a UV chamber (UV-BOX $25^{\circledR}$, Light progress, Anghiari, Italy), eggs were placed pointed end down for $15 \mathrm{~d}$ in a storage chamber (Vinotek ${ }^{\circledR}$, Liebherr, Biberach an der Riss, Germany) set at $80 \% \mathrm{RH}$ and $15^{\circ} \mathrm{C}$. During this storage period the eggs were subjected to four experimental treatments, characterised by different turning frequencies at regular intervals: no turning (control treatment) and turning once, four times, or 24 times a day, respectively. The turning angle was $45^{\circ}$ from vertical plane. After the storage period, and $18 \mathrm{~h}$ before being loaded in the incubator, all eggs were pre-warmed by maintaining them at room conditions $\left(65 \% \mathrm{RH}\right.$ and $\left.23^{\circ} \mathrm{C}\right)$. The four experimental egg groups were submitted to incubation in the same automatic incubator (Masalles HS25 ${ }^{\circledR}$, Masalles, Ripollet, Spain) set at 55\% RH and $37.8^{\circ} \mathrm{C}$ and were automatically turned every hour. On day 21 of incubation, eggs from all treatments were transferred to the same independent hatcher (1-2 $\mathrm{SA}^{\circledR}$ hatcher, Maino Enrico-Adriano S.n.C., Oltrona di San Mamette, Italy) set at $75 \% \mathrm{RH}$ and $37.5^{\circ} \mathrm{C}$, and egg turning ceased. In order to isolate and identify each hatchling, eggs were individually marked with a number and were subsequently placed in the hatcher trays inside individual, isolated boxes $(5 \times 5 \mathrm{~cm})$ made of wire net.

\section{Data recorded}

All eggs were individually weighed before storage, at setting in the incubator after the storage period, and on day 21 of incubation. Individual egg weight loss percentages were calculated during storage (relative to egg weight at the beginning of storage period), during the first $21 \mathrm{~d}$ of incubation (relative to egg weight at setting), and total weight loss (between the beginning of the storage period and on day 21 of incubation). After hatching, the number of hatchlings and unhatched eggs were recorded. Unhatched eggs were broken to determine true fertility (for the sole purpose of determining the real number of fertile eggs stored and incubated per treatment) and, if fertile, they were classified into the following categories (Ernst et al., 2004; Gómez-de-Travecedo et al., 2014a): fertile eggs without development (FND; the fertilized blastodisc, that is regular and has a distinct circular edge, dies and never develops), eggs showing positive development (PD; there is cell growth over the surface of the yolk, 


\section{Comparison of Several Turning Frequencies During the Storage Period of Red-Legged Partridge (Alectoris rufa) Hatching Eggs}

eggs, and hatchling weight. The test of KruskalWallis was applied for heteroscedastic variables, such as incubation length. Tukey's multiple range tests at the 0.05 level of significance were used to separate means. Pearson's correlation was calculated to study the relationship between pre- and poststorage weight of fertile eggs. Range (minimum and maximum), as well as coefficient of variation (\%) statistics were obtained to describe and analyse incubation length. Incubation length was tested for heteroscedasticity by Levene's test and differences in the variance of this variable among turning frequencies were also analysed by $F$ tests. Mean \pm SEM was used to indicate values of the quantitative variables. The statistical program SPSS v. 15.0 (SPSS Inc., 2006) was used to perform the statistical analyses.

\section{RESULTS}

Average fertility was $70.5 \%$. Hatchability of total eggs set was $57.5 \%$ and hatchability of the fertile eggs reached $81.6 \%$ (Table 1). Turning frequency did not affect the fertility of incubated eggs ( $p=0.573)$, the hatchability of total eggs set $(p=0.444)$ or the hatchability of fertile eggs $(p=0.439)$. In addition, turning frequency during the storage period did not influence the development stage at embryonic mortality in fertile eggs ( $p>0.05$; Table 2 ).

Table 1 - Fertility and hatchability of red-legged partridge eggs according to the turning frequency during the storage period.

\begin{tabular}{|c|c|c|c|c|c|c|}
\hline \multirow{2}{*}{$\begin{array}{l}\text { Turning frequency during } \\
\text { the storage period } \\
\text { (times a day) }\end{array}$} & \multicolumn{3}{|c|}{ Number of eggs } & \multirow{2}{*}{$\begin{array}{c}\text { Fertility }^{1} \\
(\%)\end{array}$} & \multirow{2}{*}{$\begin{array}{c}\text { Hatchability of eggs } \\
\text { set }^{2} \\
(\%)\end{array}$} & \multirow{2}{*}{$\begin{array}{c}\text { Hatchability of fertile } \\
\text { eggs }^{3} \\
(\%)\end{array}$} \\
\hline & Incubated & Fertile & Hatched & & & \\
\hline 0 & 50 & 33 & 29 & 66.0 & 58.0 & 87.9 \\
\hline 1 & 50 & 33 & 24 & 66.0 & 48.0 & 72.7 \\
\hline 4 & 50 & 38 & 31 & 76.0 & 62.0 & 81.6 \\
\hline 24 & 50 & 37 & 31 & 74.0 & 62.0 & 83.8 \\
\hline Total & 200 & 141 & 115 & 70.5 & 57.5 & 81.6 \\
\hline$p$-value & & & & 0.573 & 0.444 & 0.439 \\
\hline
\end{tabular}

${ }^{1}$ Percentage of incubated eggs that were fertile. ${ }^{2}$ Percentage of incubated eggs that hatched. ${ }^{3}$ Percentage of fertile eggs that hatched.

Table 2 - Developmental stage at embryonic mortality of red-legged partridge fertile eggs according to the turning frequency during the pre-incubation storage.

\begin{tabular}{|c|c|c|c|c|c|c|c|}
\hline \multirow{2}{*}{$\begin{array}{l}\text { Turning frequency during the storage period } \\
\text { (times a day) }\end{array}$} & \multirow{2}{*}{ Number of fertile eggs } & \multicolumn{6}{|c|}{ Development stage at embryonic mortality ${ }^{1}$ (\% of fertile eggs) } \\
\hline & & FND & PD & EEM & LEM & $P$ & Total \\
\hline 0 & 33 & 6.1 & 3.0 & 0.0 & 0.0 & 3.0 & 12.1 \\
\hline 1 & 33 & 12.1 & 6.1 & 0.0 & 3.0 & 6.1 & 27.3 \\
\hline 4 & 38 & 7.9 & 5.3 & 2.6 & 2.6 & 2.6 & 21.1 \\
\hline 24 & 37 & 10.8 & 5.4 & 0.0 & 0.0 & 0.0 & 16.2 \\
\hline Total & 141 & 9.2 & 5.0 & 0.7 & 1.4 & 2.8 & 19.1 \\
\hline$p$ value & & 0.821 & 0.947 & 0.435 & 0.568 & 0.506 & 0.431 \\
\hline
\end{tabular}

'FND: fertile, no development; PD: positive development; EEM: early embryonic mortality; LEM: late embryonic mortality; P: Pipped, dead in the shell. 


\section{Comparison of Several Turning Frequencies During the Storage Period of Red-Legged Partridge (Alectoris rufa) Hatching Eggs}

Average weight of fertile eggs before storage was $19.64 \pm 0.10 \mathrm{~g}$, and mean egg weight at setting was $19.48 \pm 0.10 \mathrm{~g}$. At these two stages, eggs turned four times a day were lighter than those that had not been turned ( $p=0.034$ and $p=0.031$, respectively; Table $3)$. Moreover, egg weight at setting was positively correlated with initial egg weight $(r=0.999, p<0.001)$. Considered jointly, egg weight losses during storage $(0.78 \pm 0.03 \%)$, incubation $(10.04 \pm 0.12 \%)$ and during the storage and incubation periods $(10.75 \pm 0.13 \%)$ did not differ among turning frequency treatments ( $p>0.05$; Table 3). After $21 \mathrm{~d}$ of incubation, the average weight of the fertile eggs was $17.53 \pm 0.09 \mathrm{~g}$, with no difference among experimental groups $(p=0.077$; Table 3).

Mean hatchling weight was $13.62 \pm 0.09 \mathrm{~g}$, with no difference among the experimental treatments $(p=0.082$; Table 4).

Table 3 - Egg weight losses during incubation in red-legged partridge fertile eggs according to the turning frequency during the storage period (mean \pm SEM).

\begin{tabular}{|c|c|c|c|c|c|c|c|}
\hline $\begin{array}{l}\text { Turning } \\
\text { frequency during } \\
\text { the storage } \\
\text { period } \\
\text { (times a day) }\end{array}$ & $\begin{array}{l}\text { Number } \\
\text { of fertile } \\
\text { eggs }\end{array}$ & $\begin{array}{l}\text { Egg weight } \\
\text { before storage } \\
\text { (g) }\end{array}$ & $\begin{array}{l}\text { Egg weight } \\
\text { before } \\
\text { incubation } \\
\text { (g) }\end{array}$ & $\begin{array}{l}\text { Egg weight } \\
\text { loss during the } \\
\text { storage period }{ }^{1} \\
(\%)\end{array}$ & $\begin{array}{l}\text { Egg weight } \\
\text { at } 21 \mathrm{~d} \text { of } \\
\text { incubation } \\
\text { (g) }\end{array}$ & $\begin{array}{l}\text { Egg weight loss } \\
\text { during the first } 21 \mathrm{~d} \\
\text { of incubation }{ }^{2} \\
(\%)\end{array}$ & $\begin{array}{c}\text { Total egg weight loss } \\
(\%)\end{array}$ \\
\hline 0 & 33 & $20.09 \pm 0.20^{a}$ & $19.93 \pm 0.20^{a}$ & $0.79 \pm 0.06$ & $17.88 \pm 0.18$ & $10.28 \pm 0.33$ & $10.98 \pm 0.34$ \\
\hline 1 & 33 & $19.67 \pm 0.20^{a b}$ & $19.53 \pm 0.20^{\mathrm{ab}}$ & $0.71 \pm 0.05$ & $17.59 \pm 0.20$ & $9.97 \pm 0.23$ & $10.62 \pm 0.24$ \\
\hline 4 & 38 & $19.28 \pm 0.20^{b}$ & $19.11 \pm 0.20^{b}$ & $0.88 \pm 0.05$ & $17.21 \pm 0.19$ & $10.00 \pm 0.21$ & $10.78 \pm 0.22$ \\
\hline 24 & 37 & $19.57 \pm 0.16^{\mathrm{ab}}$ & $19.42 \pm 0.16^{\mathrm{ab}}$ & $0.74 \pm 0.05$ & $17.49 \pm 0.15$ & $9.96 \pm 0.21$ & $10.63 \pm 0.22$ \\
\hline Total & 141 & $19.64 \pm 0.10$ & $19.48 \pm 0.10$ & $0.78 \pm 0.03$ & $17.53 \pm 0.09$ & $10.04 \pm 0.12$ & $10.75 \pm 0.13$ \\
\hline$p$ value & & 0.034 & 0.031 & 0.133 & 0.077 & 0.768 & 0.730 \\
\hline
\end{tabular}

VValues expressed as a percentage of egg weight at the beginning of storage period. ${ }^{2}$ Values expressed as a percentage of egg weight at the beginning of incubation. ${ }^{3}$ Values are expressed as a percentage of egg weight loss between the beginning of the storage period and day 21 of incubation. ${ }^{a, b}$ Means in the same column with different superscripts are significantly different $(p<0.05)$.

Table 4 - Hatchling weight and incubation length in red-legged partridge eggs according to the turning frequency during the pre-incubation storage.

\begin{tabular}{|c|c|c|c|c|c|c|c|}
\hline \multirow{2}{*}{$\begin{array}{l}\text { Turning frequency during the } \\
\text { storage period } \\
\text { (times a day) }\end{array}$} & \multirow{2}{*}{$\begin{array}{c}\text { Number of chicks } \\
\text { hatched }\end{array}$} & \multirow{2}{*}{$\begin{array}{l}\text { Hatchling weight } \\
\text { (g; Mean } \pm \text { SEM) }\end{array}$} & \multicolumn{5}{|c|}{$\begin{array}{l}\text { Incubation length } \\
\text { (d) }\end{array}$} \\
\hline & & & Mean \pm SEM & Variance & $\mathrm{CV}^{1}(\%)$ & Min & Max \\
\hline 0 & 29 & $13.98 \pm 0.17$ & $23.29 \pm 0.16$ & $0.76^{x}$ & 3.74 & 22.50 & 26.00 \\
\hline 1 & 24 & $13.51 \pm 0.22$ & $23.63 \pm 0.20$ & $0.92^{x}$ & 4.06 & 22.50 & 25.50 \\
\hline 4 & 31 & $13.37 \pm 0.16$ & $23.40 \pm 0.09$ & $0.27^{y}$ & 2.24 & 22.50 & 24.50 \\
\hline 24 & 31 & $14.61 \pm 0.14$ & $23.50 \pm 0.13$ & $0.52^{x y}$ & 3.06 & 22.50 & 25.50 \\
\hline Total & 115 & $13.62 \pm 0.09$ & $23.45 \pm 0.07$ & 0.59 & 3.29 & 22.50 & 26.00 \\
\hline$p$ value & & 0.082 & 0.497 & 0.002 & & & \\
\hline
\end{tabular}

${ }^{1} \mathrm{CV}$ : Coefficient of variation. ${ }^{x-y}$ Variances in the same column with different superscripts are significantly different $(p<0.05)$.

The mean incubation period lasted $23.45 \pm 0.07 \mathrm{~d}$ and was independent of egg-turning frequency during the storage period ( $p=0.497$; Table 4). A lower variance of the incubation length was found for eggs turned four times a day compared with unturned eggs and eggs turned once a day, while eggs turned 24 hours a day showed an intermediate variance of this variable.

\section{DISCUSSION}

The fertility, hatchability of the incubated eggs and hatchability of the fertile eggs found in this trial were within the ranges described for farmed red-legged partridge by several authors (fertility: 50.2-89.7\%, hatchability: $30.6-86.4 \%$, and hatchability of the fertile eggs: 57.5-91.6\%; Bagliacca et al., 1988; Paci et al., 1992; González-Redondo, 2006, 2010; Mourão et al., 2010; Gómez-de-Travecedo et al., 2014a, 2014b, 2014c; González-Redondo \& Díaz-Merino, 2016). As hatchability did not vary among turning frequency treatments, it can be considered that all turning frequencies tested during storage, including the absence of turning, provided suitable hatchability. Our results confirm previous knowledge in alternative poultry species. They agree, therefore, with Woodard \& Morzenti (1975), who found that turning chukar partridge (Alectoris chukar), pheasant (Phasianus colchicus) and Japanese quail (Coturnix coturnix japonica) eggs once a day before incubation had no appreciable effect on the hatchability of eggs stored up to $28 \mathrm{~d}$. The results are also consistent with those of Miller \& Wilson (1976), who reported that turning 
bobwhite quail (Colinus virginianus) eggs during the preincubation storage period does not affect hatchability. Our results do not support, however, several published recommendations concerning red-legged partridge game farming; Setién (1991), for example, advises turning eggs every 30-60 min, while Llauradó (1987) and Peña \& Caballero (1997) state that turning them twice a day suffices. However, the present study agreed with Cancho (1991), who considers it unnecessary to turn $A$. rufa eggs during storage.

The negative effect on hatchability due to the absence of egg turning described in the literature for the chicken (Gallus gallus) is mainly caused by abnormal adhesion of the embryo to the inner shell membrane, leading to higher incidence of embryo malposition, as well as impairment of albumen utilisation, yolk sac development and fluids distribution in the egg (Decuypere \& Bruggeman, 2007). However, the effect of turning of chicken eggs during storage before incubation on hatchability remains controversial. The studies of Mahmud \& Pasha (2008) on broiler eggs turned 24 times a day during a 5-d storage period; Khan et al. (2012) on broiler eggs turned 3 to 12 times a day during a 6-d storage period and Tiwary \& Maeda (2005) in layer eggs turned twice a day during 3- to 4-wk storage periods did not find any improvement in hatchability compared with unturned eggs. Conversely, improved hatchability was reported by Elibol et al. (2002) in broiler eggs turned 4 or 24 times a day during 3- to 14-d storage periods; by Mousa-Balabel \& Saleem (2004) in broiler eggs turned 3 to 12 times a day during a 6-d storage period, and by Machado et al. (2010) in broiler grandparents' eggs turned 24 times a day during $16 \mathrm{~d}$ of storage, compared with unturned eggs. As reviewed by Elibol et al. (2002), there seems to be no advantage in turning when chicken hatching eggs are stored pointed end down for short periods (mostly less than $10 \mathrm{~d}$ ), while it seems to be beneficial in longer storage periods. This could explain the absence of positive effects of egg turning during storage in red-legged partridges in the present study because the eggs were stored for a medium-term period of 15 $\mathrm{d}$, while it is known that $A$. rufa eggs can be stored for at least 4 wks without significant loss of viability (González-Redondo, 2010; Gómez-de-Travecedo et al., 2014a, 2014b), as also occurs in other Alectoris species (Woodard \& Morzenti, 1975). In this context, further research should elucidate whether egg turning during storage periods longer than a month could improve the hatchability of red-legged partridge eggs.

Embryonic mortality rate and the development stage at which embryonic mortalities recorded in the present trial are consistent with those of similar studies related to artificial incubation of red-legged partridge eggs (Gómez-de-Travecedo et al., 2014a, 2014b, 2014c). As embryonic mortality and the development stage at which embryonic mortalities occurred did not vary among turning frequency treatments, it may be considered that all turning frequencies tested during storage, including the absence of turning, provided suitable embryo performance. Furthermore, Elibol et al. (2002) state that there is no obvious relationship between turning 4 and 24 times a day during storage and the percentage of early or late dead embryos in broiler eggs stored between 3 and $14 \mathrm{~d}$. However, Machado et al. (2010), in broiler grandparents' eggs stored for $16 \mathrm{~d}$ and turned 24 times a day, and Bowman (1969), in layer eggs stored and turned between 7 and $28 d$, found a reduction in embryonic mortality at all stages of the incubation compared with unturned eggs. Khan et al. (2012) also report lower early embryonic mortality during incubation in broiler eggs turned 3 to 12 times a day during a 6-d storage period, compared with unturned eggs. As for hatchability, the advantage for embryo survival due to turning increases with longer storage periods (Bowman, 1969). This could explain the absence of effects in the present trial because a medium-term storage period was chosen.

It is relevant, however, to note that while the absence of egg-turning during the storage period does not have any detrimental effects on hatchability and embryonic performance, turning them during incubation is essential in red-legged partridges due to the fact that ceasing to turn eggs early during incubation increases embryonic mortality (Llauradó, 1987; Cancho, 1991; Setién, 1991; Peña \& Caballero, 1997) and reduces hatchability (González-Redondo \& De la Rosa Sánchez, 2009).

Mean weight of recently-laid fertile eggs and egg weight loss during storage and during the first $21 \mathrm{~d}$ of incubation results agree with those described for red-legged partridges reared in game farms (GonzálezRedondo, 2010; Mourão et al., 2010; Gómez-deTravecedo et al., 2014a, 2014b, 2014c; GonzálezRedondo \& Díaz-Merino, 2016). As expected, egg weight losses were not affected by the turning frequency during egg storage. In fact, none of the studies reviewed in the literature assess the potential effect of turning eggs on weight loss during storage and incubation.

Hatchling weights recorded in this trial was similar to the mean values described for red-legged 
partridges in captivity (13.8-14.3 g, according to Gómez-de-Travecedo et al., 2014a, 2014b, 2014c; González-Redondo \& Díaz-Merino, 2016) and was not modified by the turning frequency during storage. A visual inspection showed that hatchling quality and performance was normal. Our results do not support those of Mousa-Balabel \& Saleem (2004) and Khan et al. (2012), who describe an increase in broiler hatchling weight when the eggs were turned 3 to 12 times a day compared with unturned eggs stored for $6 \mathrm{~d}$.

The mean length of the incubation period obtained in this research fitted the 23.4-d period reported for artificially-incubated red-legged partridge eggs (González-Redondo et al., 2012). While the modification of other parameters, e.g., storage period length (Gómez-de-Travecedo et al., 2014a, 2014b) or incubation temperature (Gómez-de-Travecedo et al., 2014c) alters incubation length, egg-turning frequency during storage did not affect its average value. The lower variance of the incubation period found in this trial for eggs turned four times a day compared with unturned eggs and eggs turned once a day partially agrees with Mousa-Balabel \& Saleem (2004), who describe a reduction in the hatching time in broiler eggs turned 3 to 12 times a day compared with unturned eggs stored for $6 \mathrm{~d}$. However, it must be taken into account that our data are not strictly comparable with those of Mousa-Balabel \& Saleem (2004) because these authors measured hatching time as the time elapsed from loading the eggs in the incubator to the hatching of the last egg in the batch. We, however, calculated the mean incubation length for each experimental batch as the difference between incubator loading and hatching date of each single egg. In the present study, the maximum incubation length of the last egg hatched in the unturned batch was $26.0 \mathrm{~d}$, while the last eggs hatched at 25.50 and $24.50 \mathrm{~d}$ in the batches submitted to turning (Table 4), which partially agrees with Mousa-Balabel \& Saleem (2004). Consequently, further research is necessary to elucidate whether egg turning during storage modifies hatching synchrony, as suggested by the results of Mousa-Balabel \& Saleem (2004) results and by our data. However, it is not clear why the variance of incubation length of the eggs turned 24 times a day had an intermediate value compared with those turned four times a day and eggs turned once a day or unturned. In this sense, it will be interesting to investigate the effects of egg turning during long storage periods on egg quality, embryo viability, and embryo developmental stage at the end of storage period.

\section{CONCLUSION}

Turning red-legged partridge eggs one, four or 24 times a day during a storage period of $15 \mathrm{~d}$ before incubation did not influence hatchability, hatchling weight, or incubation length compared with unturned eggs. Hatching synchrony seemed to be affected by the egg-turning regime. Therefore, further research is necessary to confirm the recommendation from several informative publications advising $A$. rufa eggs be turned during medium-term storage periods before incubation.

\section{CONFLICT OF INTEREST}

No potential conflict of interest was found by the authors.

\section{REFERENCES}

Bagliacca M, Mori B, Gualterio L. Egg laying under artificial photo-regulation in the red partridge. Proceedings of the 18th World's Poultry Congress; 1988; Nagoya. Japan. p. 657-659.

Bowman JC. Storage of hatching eggs. 2. Evidence of genotype $x$ environment interactions. British Poultry Science 1969;10:19-28.

Cancho M. Incubación. Equipo y técnicas de manejo. Control. In: Fundación La Caixa. La perdiz roja. Barcelona: AEDOS; 1991. p. 21-27.

Damaziak K, Pawęska M, Gozdowski D, Niemie, J. Short periods of incubation, egg turning during storage and broiler breeder hens age for early development of embryos, hatching results, chicks quality and juvenile growth. Poultry Science 2018;97:3264-3276.

Decuypere E, Bruggeman V. The endocrine interface of environmental and egg factors affecting chick quality. Poultry Science 2007;86:1037-1042.

Elibol O, Peak SD, Brake J. Effect of flock age, length of egg storage, and frequency of turning during storage on hatchability of broiler hatching eggs. Poultry Science 2002;81:945-950.

Ernst RA, Bradley FA, Abbott UK, Craig RM. Egg candling and breakout analysis [cited 2017 Jul 17]. Davis: University of California; 2004. Available from: http://anrcatalog.ucdavis.edu/pdf/8134.pdf.

Gómez-de-Travecedo P, Caravaca FP, González-Redondo P. Effects of storage temperature and length of the storage period on hatchability and performance of red-legged partridge (Alectoris rufa) eggs. Poultry Science 2014a;93:747-754.

Gómez-de-Travecedo P, Caravaca FP, González-Redondo P. Effects of prestorage incubation of red-legged partridge (Alectoris rufa) eggs on hatchability and incubation length. International Journal of Agriculture and Biology 2014b;16:513-520.

Gómez-de-Travecedo P, Caravaca FP, González-Redondo P. Effects of the time to change from incubation to hatching temperature on the artificial incubation of red-legged partridge (Alectoris rufa) eggs. Spanish Journal of Agricultural Research 2014c;12:727-731.

González-Redondo P. Influence of the laying date on the fertility and hatchability of red-legged partridge (Alectoris rufa) eggs. Journal of Applied Poultry Research 2006;15:579-583. 


\section{González-Redondo P,} Martínez-Domínguez AR
González-Redondo P. Effect of long-term storage on hatchability of redlegged partridge (Alectoris rufa) eggs. PoultryScience 2010;89:379383.

González-Redondo P, De la Rosa Sánchez S. Efecto de la duración de la fase de volteo de los huevos de perdiz roja (Alectoris rufa) durante la incubación sobre la tasa de eclosión. ITEA-Información Técnica Económica Agraria 2009;105:291-295.

González-Redondo P, Delgado-Pertíñez M, Toribio S, Ruiz FA, Mena Y, Caravaca FP, Castel JM. Characterisation and typification of the redlegged partridge (Alectoris rufa) game farms in Spain. Spanish Journal of Agricultural Research 2010;8:624-633.

González-Redondo P, Díaz-Merino R. Comparison of three temperatures for the hatching phase in the artificial incubation of red-legged partridge (Alectoris rufa) eggs. Revista Brasileira de Ciência Avícola 2016:18:5762.

González-Redondo P, Gutiérrez-Escobar R, Díaz-Merino R, Panea-Tejera P, Martínez-Domínguez AR. Duración de la incubación artificial en perdiz roja (Alectoris rufa). ITEA-Información Técnica Económica Agraria 2012;108:289-297.

Khan MJ, Abbas A, Ayaz M, Naeem M, Qadir S, Akhter MS, et al. Effect of pre-heating and turning during storage period on hatchability and post hatch performance of broilers. ISCA Journal of Biological Sciences; 2012:1(2):1-6.

Llauradó L. Incubación artificial de huevos de perdiz. Selecciones Avícolas 1987;29:144-147.

Machado AR, Silva MS da, Fonseca BB. Viragem de ovos de avós pesadas (Gallus gallus) durante a estocagem [cited 2017 Jul 24]. Revista Avisite 2010; Available from: http://www.avisite.com.br/cet/img/20100419_ viragem.pdf.

Mahmud A, Pasha TN. Effect of storage, pre-heating and turning during holding period on the hatchability of broiler breeder eggs. Pakistan Veterinary Journal 2008;28:153-154.

\section{Comparison of Several Turning Frequencies During the Storage Period of Red-Legged Partridge (Alectoris rufa) Hatching Eggs}

Miller ER, Wilson HR. Hatchability of bobwhite quail eggs as influenced by pre-incubation storage and turning. Poultry Science 1976;55:24762478.

Mousa-Balabel TM, Saleem EKY. Effect of selection and duration of storage of broiler hatching eggs on hatchability percent and chick weight. Kafr El-Sheikh Veterinary Medical Journal 2004;2:197-208.

Mourão JL, Barbosa AC, Outor-Monteiro D, Pinheiro VM. Age affects the laying performance and egg hatchability of red-legged partridges (Alectoris rufa) in captivity. Poultry Science 2010;89:2494-2498.

Paci G, Marzoni M, Benvenuti N, Bagliacca M. Breeding technology of redpartridges: colonies or couples. Proceedings of the $19^{\text {th }}$ World's Poultry Congress; 1992; Amsterdam. Netherlands. v.3, p.351-352.

Peña JC, Caballero JR. La explotación cinegética de la perdiz. In: Buxadé C, editor. Zootecnia. bases de producción animal. producciones cinegéticas, avícolas y otras. Madrid: Mundi-Prensa; 1997. v.12, p.87108.

Setién M. Producción cinegética: granjas de perdices. In: Fuentes A, Sánchez I, Pajuelo L, editors. Manual de ordenación y gestión cinegética. Badajoz: IFEBA; 1991. p.133-152

SPSS. Manual del usuario de SPSS Base 15.0. Chicago: SPSS; 2006

Tiwary AK, Maeda T. Effects of egg storage position and injection of solutions in stored eggs on hatchability in chickens (Gallus gallus). Journal of Poultry Science 2005;42:356-362.

Woodard $A E$, Morzenti A. Effect of turning and age of egg on hatchability in the pheasant, chukar, and Japanese quail. Poultry Science 1975;54:1708-1711. 
